\title{
Teknologi Sediaan Oral Lapis Tipis Terlarut Cepat (Fast Dissolving Film)
}

\author{
Tengku Ruhul Fajria, Rina Fajri Nuwarda \\ Fakultas Farmasi Universitas Padjadjaran \\ Jl. Raya Bandung Sumedang km. 21 Jatinangor, 45363 \\ email: tengku.ruhul15@gmail.com
}

\section{Abstrak :}

Teknologi sediaan oral lapis tipis terlarut cepat pertama kali dikembangkan pada tahun 1970-an sebagai alternatif dari penggunaan tablet untuk beberapa pasien yang mengalami kesulitan dalam menelan (anak-anak dan geriatri). Film lapis tipis menjadi sebuah pendekatan baru untuk bentuk sediaan obat karena penggunaannya yang lebih mudah dan lebih nyaman dibandingkaan dengan bentuk sediaan oral. Film lapi tipis terlarut cepat adalah bentuk sediaan padat tipis yang ketika ditempatkan dimulut akan larut dalam beberapa detik, sehingga oabat-obat dapat langsung menuju sirkulasi sistemik tanpa mengalami first pass effect metabolism. Formulasi film lapis tipis terdiri atas zat aktif dan eksipien (polimer, plasticizer, pemanis, perisa, dan lainnya). Film yang ideal harus memiliki sifat-sifat seperti warna yang seragam, rasa yang disukai, stabilitas tinggi, dan penangan yang mudah.

Kata kunci: Oral, Film Lapis Tipis, Terlarut Cepat.

\section{Outline}

- Pendahuluan

- Formulasi dan bahan

- Evaluasi Sediaan Film Lapis Tipis Oral

- Kesimpulan

\section{Pendahuluan}

Dibandingkan dengan bentuk sediaan lainnya, rute oral merupakan jalur pemberian yang sangat nyaman, hemat biaya, dan disukai oleh kebanyakan pasien. Akan tetapi, tidak semua sediaan oral bisa digunakan terutama untuk pasien pediatri, geriatri, pasien yang sulit untuk menelan, dan pasien yang tidak patuh. Perkembangan terbaru dalam teknologi pembuatan sediaaan obat akhir-akhir ini mampu membantu beberapa permasalahan di atas. Berbagai sediaan mukosa bioadhesif telah dikembangkan, yang meliputi tablet perekat, gel, salep, patch, dan beberapa bentuk sediaan lainnya yang menggunakan polimer termasuk salah satunya film terlarut cepat (Malke et al, 2007)

Sediaan oral lapis tipis terlarut cepat pertama kalinya dikembangkan pada tahun 1970-an. Bentuk sediaan ini terdiri atas sediaan solid yang terintegrasi dan telarut cepat di dalam rongga mulut tanpa membutuhkan air. Sediaan film lapis tipis terlarut cepat adalah film ultra tipis yang menggunakan polimer hidrofilik sehingga sangat cepat terhidrasi atau melekat ketika ditempatkan di lidah attau rongga mulut (Avinash, 2013). 
Film-film kemudian akan hancur atau terlarut beberapa detik dan melepaskan zat aktif tanpa memerlukan air atau pun mengunyah, sehingga sediaan ini sangat mudah sampai ke pembuluh darah dan menghasilkan ketersediaan hayati yang baik (Shweta dan Mayank, 2012; Swamy dan Shiva, 20114).

Sediaan film lapis tipis biasanya dirancang untuk obat-obatan yang umumnya memiliki first pass effect metabolism yang tinggi, sehingga dengan menggunakan teknologi film terlarut cepat akan meningkatkan ketersediaan hayati obat dan menurunkan first pass effect meetabolism (Sri et al, 2015).

Adapun beberapa keuntungan dari penggunaan teknologi sediaan oral lapis tipis terlarut cepat adalah sebagai berikut:

- Terhindar dari risiko tersedak

- Terhindar dari proses first pass effect metabolism dan memberikan onset kerja yang lebih cepat.

- Memiliki stabilitas yang baik

- Tidak membutuhkan air

- Luas permukaan yang besar akan memberikan disintegrasi dan pelarutan obat yang cepat pada rongga mulut.

- Mudah diberikan kepada pasien yang menderita disfagia, emesis lambung, serta gangguan mental.

- Ketepatan dosis

- Daat mencegah lingkungan yang asam di dalam lambung

- Dapat dipakai untuk pemberian lokal maupun sediaan sistemik

- Fleksibel dan mudah dibawa kemana mana, sehingga meningkatkan kepatuhan pasien.

- Cocok diberikan untuk pasien geriatrik maupun pediatrik, dimana pada umumnya memilki kesulitan menelan, gangguan mental, atau pasien yang sedang dalam keadaan cairan berkurang atau mual.

(Sandep et al, 2011; Arya et al, 2010)

Ada beberapa kekurangan dari teknologi sediaan lapis tipis terlarut cepat yang dapat menyebabkan sediaan ini tidak bisa digunakan untuk semua jenis obat. Sifat fisikokimia obat, stabilitas, dan tujuan terapi harus diperhatikan dalam penggunaan teknologi ini.

Berikut adalah beberapa kekurangan dari film lapis tipis oral:

- Obat dengan dosis tinggi tidak dapat dimasukkan dalam film

- Obat obat yang menyebabkan iritasi pada mukosa tidak dapat diberikan pada bentuk sedian ini.

- Memerlukan kemasan yang khusus, karena mudah terdegredasi dan sifatnya rapuh.

- Packaging yang mahal

- Karena sedian ini terlarut cepat, maka penghentian dosis tidak mungkin untuk dilakukan.

- Termasuk sediaan yang baru dan belum banyak penelitiannya

(Naziya et al, 2013) 


\section{Formulasi dan Bahan}

\section{Zat Aktif}

Komposisi zat aktif pada formulasi film adalah $1-25 \%$ b/b obat. Molekul yang memiliki ukuran yang kecil sangat baik untuk formulasi sediaan lapis tipis terlarut cepat. Beberapa zat aktif sangat baik di formulasikan dengan teknologi ini, seperti zat aktif yang rasanya pahit, dengan menggunakan teknologi ini rasa pahit pada beberapa obat dapat ditutupi dengan penggunaan film dan juga dapat ditambahkan beberapa eksipien dengan rasa yang disukai (Koland, Sandeep, dan Charyulu, 2010).

Beberapa golongan obat dapat diformulasikan sebagai film yang larut dalam mulut, misalnya anti-tussive, ekspektoran, anti asma, anti epilepi, anti emetik, antipiretik, dan anti parkinson (Dnyaneshwas et al, 2014; Apoorva et al, 2011). Beberapa obat yang cocok diformulasikan pada teknologi film lapis tipis terlarut cepat berdasarkan katagorinya adalah tercantum pada tabel 1 dibawah ini (Dnyaneshwas et al, 2014; Apoorva et al, 2011; Alpesh et al, 2010).

Tabel 1. Obat yang cocok pada formulasi film lapis tipis terlarut oral

\begin{tabular}{|c|c|}
\hline Golongan & Contoh \\
\hline Anti emetik & $\begin{array}{l}\text { Ondansetron,0Granisetron,0Plonosetron,hDronabinol, } \\
\text { Aprepitant,tRamosetron,gTrimethobezamide, } \\
\text { Nabilone,hMetoclopramide,kDolasetron, Dimenhydramine }\end{array}$ \\
\hline $\begin{array}{l}\text { Seretonin } \\
\text { inhibitors }\end{array}$ & $\begin{array}{l}\text { Fluoxetine,gSetraline,hParoxetine,hFluxoamine, } \\
\text { CitalopramhandhAlaproclate }\end{array}$ \\
\hline 5HT3 antagonis & $\begin{array}{l}\text { Alosetron,uOndansetron, rGranisetron,gPalonosetron, } \\
\text { RmosetronfandhTropisetron }\end{array}$ \\
\hline Anti Epilepsi & $\begin{array}{l}\text { Carbamezapine,yClonazepalm,yDiazepam, } \\
\text { Divalproexysodium,yFosphenyloin,yGabapentin, } \\
\text { Lamotrigine,yLevetiracetam,yOxacarbazepine, } \\
\text { Phenytoin,yPrimidoneyandyValproateysodium }\end{array}$ \\
\hline Anti migrain & $\begin{array}{l}\text { Almotriptan, Dihydrogotamine Mesylate, Eletriptan, Frovatriptan, } \\
\text { NaratriptanRizatriptan, Sumatriptan and Zolmitriptan }\end{array}$ \\
\hline $\begin{array}{l}\text { Dopamin D1 and } \\
\text { D2 Antagonist }\end{array}$ & $\begin{array}{l}\text { A misulpride, Bromperidol, Cabergoline, Domeperidone, } \\
\text { Fenoldopam, Halopiridol, Metoclopramide, Metopimazine, } \\
\text { PergolideMesylate, Prochlorperazine, Quetiapine, Ropinirole } \\
\text { Hydrochloride, Sulpiride, Tiapride and Zotepine }\end{array}$ \\
\hline Statins & $\begin{array}{l}\text { Atorvastatin, Cerivastatin, Fluvastatin, Lovastatin, Pitavastatin, } \\
\text { Pravastatin, Rosuvastatin and Simvastatin }\end{array}$ \\
\hline
\end{tabular}




\section{Polimer}

Untuk formulasi film yang bersifat larut dalam air, polimer yang digunakan harus larut dalam air, dengan berat molekul yang rendah dan kapasitas pembentukan film yang baik. Polimer yang digunakan tidak beracun, tidak menyebabkan iritasi, dan tidak memiliki pengotor yang daat larut. Seain itu tidak boleh menyebabkan efektivitas zat aktif berubah. Polimer seharusnya kemampuan menyebar yang baik, agar seluruh zat aktif terlindungi dan cukup kuat (Bala et al, 2013). Polimer terdiri atas polimer alami seperti pullulan, pati, gelatin, natrium alginat, maltodextrin, xanthan, dsb, dan polimer sintesis seperti HPMC, Na-CMC, HPC, PVA, dsb (Priynka et al, 2011).

\section{Plasticizer}

Plasticizer membantu meningkatkan fleksibilotas serta mampu mengurangi kerapuhan film, sehingga film tidak mudah pecah. Namun, penggunaan plasticizer yang tidak tepat justru akan membuat film menjdi retak, membelah, serta terkelupas. Plasticizer yang umumnya digunakan adalah gliserol, propilenglikol, dll (Mashru et al, 2005).

\section{Pemanis}

Pemanis merupakan komponen yang penting dalam formulasi sediaan yang hancur ataupun terlarut dalam mulut. Pemanis yang digunakan pada film terlarut cepat ini dapat berupa pemanis alami maupun pemanis buatan. Akan tetapi, penggunaan pemanis alami (ribosa, glukosa, mannosa, galaktosa, fruktosa, dekstrosa, sukrosa, maltosa, dsb) harus dibatasi terutamapada orang yang sedang mengalami diet atau pada penderita diabetes. Karena hal inilah, pemanis buatan semakin populer digunakan dalam makanan dan juga sediaan farmasi. Contoh pemanis buatan adalah sakarin, aspartam, dan siklamat (Subash et al, 2010).

\section{Saliva stimulating agent}

Penggunaan saliva stimulating agent atau perangsang air liur adalah untuk membantu meningkatkan laju produksi air liur yang dapat menyebabkan sediaan mudah terdisintegrasi dan film-flm cepat larut. Umumnya, penggunaan asam dapat meningkatkan produksi air liur, seperti asam sitrat, asam malat, asam askorbat, asam laktat, dan juga asam tartarat (Desai dan Basu, 2012).

\section{Perisa}

Penggunaan perisa dibutuhkan pada formulasi agar memberikan kualitas yang baik saat produk terlarut di dalam mulut. Pemilihan perisa tergantung pada jenis obat yang akan dikonsumsi. Selain itu, penggunaan perisa juga memerhatikan tingkatan usia. Pada geriatri, biasanya rasa yang digunakan adalah mint dan jeruk. Sedangkan paada ussia remaja, biasa digunakan kombinasi buah-buahan yag lebih bervariasi. Zat peerisa dapat berasal dari minyak-minyak seperti minyak peppermit, minyak kayu manis, dan minyak pala. Atau dapat pula berasal dari sari buah, seperti pada rasa vanila, kopi, coklat, jeruk, dan laiinya (Puthil dan Dixit, 2009). 


\section{Surfaktan}

Surfaktan berfungsi sebagai zat pelarut atau zat pembaasah dalam formulasi sehingga film larut dengaan cepat dan melepaskan zat aktif pada rongga mulut. Beberapa surfaktan yang umum digunakan adalah Tween, Sodium laurit sulfat, benzalkonium klorida, dan sebagainya (Petel et al, 2010).

\section{Metode Pembuatan Film Lapis Tipis Oral}

Beberapa metode yang digunakan dalam proses pembuatan sediaan film lapis tipis terlarut cepat adalah :

\section{Metode Penuangan Pelarut (Solvent Casting Method)}

Metode ini adalah metode yang sering atau banyak digunakan oleh beberapa perusahaan dalam membuat sediaan film lapis tipis terlarut cepat. Proses pembuatannya terdiri dari:

- Polimer dan plasticizer yang larut air dilarutkan kedalam pelarut yang mudah menguap seperti etanol atau air destilasi untuk membentuk larutan kental yang jernih.

- Larutan kemudian dimasuk selama 2 jam dengan menggunakan pengaduk maagnetik, dan disisihkan.

- Zat aktif serta eksipien lainnya dilarutkan ke dalam pelarut polar (air) dan udara yang terperangkap dihilangkan dengan cara di vakum.

- Kemudian, zat aktif dan bahan film dimasukkan ke dalam cawan petri yang memiliki ukuran yang sesuai. Dikeringkan dalam oven dengan suhu dan waktu yang sesuai.

- Film yang telah terbentuk kemudiaan dipotong menjadi ukuran dan bentuk yang diinginkan

(Nehal et al, 2011; Padya et al, 2013)

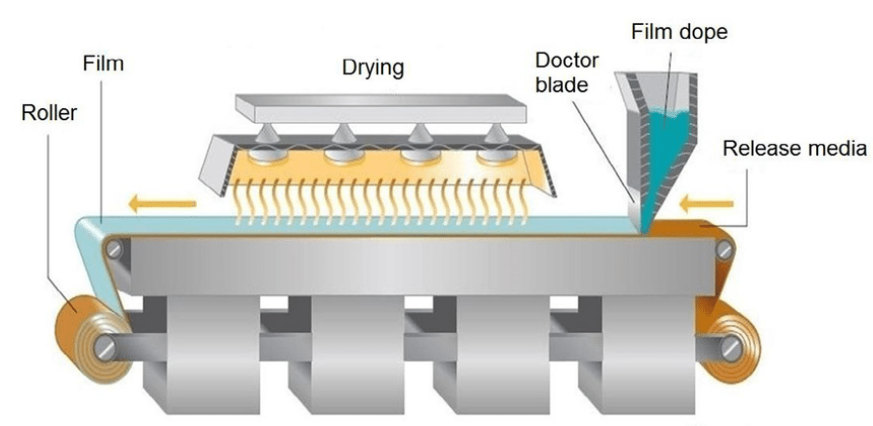

Gambar 1. Metode Penuangan Pelarut (Nehel et al, 2011)

Metode Penuangan Semi-solid (Semi-solid Casting Method)

Metode ini jarang digunakan dalam proses pembuatannya. Tapi metode ini bisa menjadi salah satu alternatif dalam pembuatan film lapis tipis ini. 
Proses pembuataannya sebagai berikut:

- Larutan polimer yang larut dalam air disiapkan kemudian dituangkan ke dalam larutan asam dengan perbandingan 1:4 (misalnya selulosa asetat butirat).

- Kemudian ditambahkan sejumlah plasticizer untuk membentuk masa gel.

- Kemudian dicampur bersamaan dengan film dengan menggunakan panas.

- Ketebalan harus dikontrol sekitar 0,015 -0,05 inci

(Nehal et al, 2011; Padya et al, 2013)

\section{Metode Ekstruksi Lebur Panas (Hot Melt Extruction Method)}

Metode ini sering digunakan dalam pembuatan film lapis tipis terlarut oral, terutama digunakan dalam proses penyiapan granul, sediaan lepas lambat, dan obat obat dengan rute pemberian transdermal dan transmucosal. Tahap-tahap yang dilakukan adalah:

- Zat aktif dicampur dengan pembawa yang berbentuk padat.

- Kemudian campuran dilelehkan dengaan menggunakan alat ekstruder yang memiliki pemanas.

- Selanjutnya lelehan akan membentuk film yang sesuai.

(Nehal et al, 2011; Padva et al. 2013)

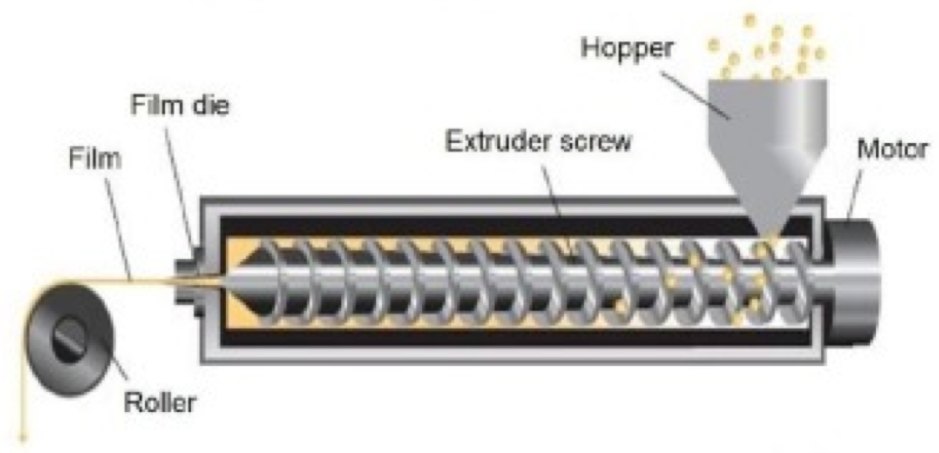

Gambar 2. Metode Ekstruksi Lebur Panas (Nehal et al, 2011)

Metode Dispersi Solid (Solid Dispersion Method)

Metode ini dilakukan dengan tambahan polimer hidrofilik amorf. Dimana satu atau lebih bahan aktif nantinya akan didispersikan dalam pembawa inert yang berbentuk padat.

Tahapan yang dilakukan adalah sebagai berikut:

- Zat aktif dilarutkan ke dalam pelarut yang sesuai

- Larutan kemudian ditambahkan ke dalam lelehan polimer (PEG) pada suhu dibawah $700 \mathrm{C}$ tanpa menghilangkan pelarut, sehingga membentuk dispersi padat.

- Kemudian dicetak, sehingga dispersi padat akan berubah menjadi film.

(Nehal et al, 2011; Padya et al, 2013; Repka et al, 2003)

Metode Penggilingan (Rolling Method)

Pada metoe penggilingan, larutan atau suspensi yang mengandung bahan obat digiling bersamaan dengan pembawanya. 
Pelarut yang digunakan adalah air dan campuran air dengan alkohol. Kemudian, film yang telah dibentuk dikeringkan pada roller, dan dipotong sesuai dengan bentuk dan ukuran yang diinginkan (Mahtre dan Khanekar, 2012).

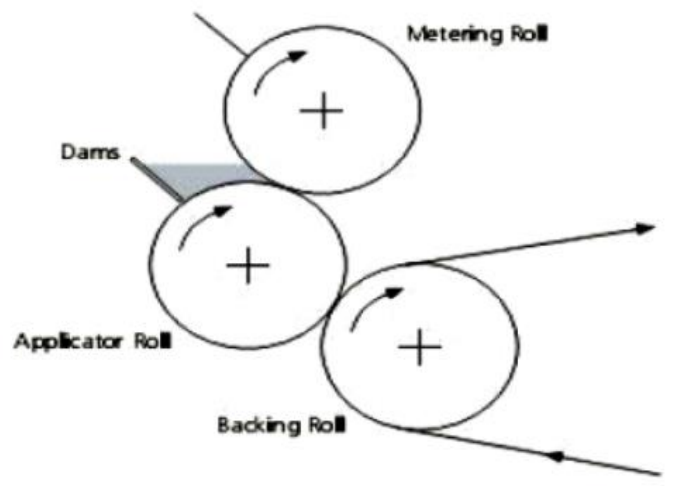

Gambar 3. Metode Penggilingan

\section{Evaluasi Sediaan Film Lapis Tipis Oral}

\section{Evaluasi organoleptik}

Evaluasi organoleptik meliputi evaluasi warna, bau, dan rasa. Film lapis tipis oral harus memiliki warna yang menarik dan harus seragam pada semua sediaan. Sedangkan rasa yang digunakan harus mampu menutupi rasa tidak enak dari zat aktif atau eksipien. Rasa merupakan faktor yang penting dalam penerimaan pasien (Gowri et al, 2014; Rajini et al, 2013)

\section{Evaluasi $\mathrm{pH}$}

Evaluasi $\mathrm{pH}$ merupakan hal yang penting. $\mathrm{pH}$ permukaan film yang tidak tepat dapat menyebabkan iritasi pada mukosa mulut. Oleh sebab itu, $\mathrm{pH}$ permukaan film harus netral, yaitu 7 atau mendekati 7 . Pemeriksaan $\mathrm{pH}$ film dapat dilakukan dengan menggunkan elektroda. Film mulanya dibasahi dengan air dan diukur $\mathrm{pH}$ menggunakan elektroda. Evaluasi $\mathrm{pH}$ setidaknya dilakukan pada 6 film dan rata rata akhir mendekati syarat yang ditetapkan. Metode lainnya yang dapat digunakan untuk menentukan $\mathrm{pH}$ permukaan film adalah dengan menggunakan gel agar $1,5 \%$ dan kemudian film diletakkan diatasnya. $\mathrm{pH}$ permukaan selanjutnya dapat diukur dengan menggunakan kertas pH (Gowri et al, 2014; Rajini et al, 2013).

\section{Evaluasi Keseragaman Kadar}

Pengujian keseragaman kadar dilakukan dengan menyiapkan film berukuran $2 \times 2 \mathrm{~cm} 2$ yang ditempatkan kedalam wadah yang berisikan $10 \mathrm{ml}$ medium yang sesuai. Kemudian, sampel diaduk dengan menggunakan pengaduk untuk melarutkan film. Sampel kemudian diukur pada panjang gelombang tertentu. Keseragaman kadar ditentukan dengan memperkirakan kadar zat aktif dalam sediaan film. Syarat yang ditetapkan adalah 85-115\% (Gohel et al, 2007). 


\section{Evaluasi Ketebalan Film}

Evaluasi ketebalan film dilakukan dengan menggunakan Micrometer Screw Gauge pada beberapa lokasi berbeda. Hasil akhir evaluasi ini kemudian diambil rataan pada 6 kali bacaan. Syarat ketebalan film berikisar antara 11-10 mm (Singh et al, 2010).

\section{Evaluasi Transparansi Film}

Uji transparansi film dilakukan dengan menggunakan spektrofotometer UV sederhana. Film diambil kemudian ditempatkan di bagian internal spektrofotometer sel dan kemudian dianalisis pada panjang gelombang $600 \mathrm{~nm}$. Transparansi film dapat dihitung dengan menggunakan rumus berikut :

Transparansi $=(\log T 600) / B=-€ \mathrm{C}$

Dimana :

T600 = Transmitan pada panjang gelombang $600 \mathrm{~nm}$

$\mathrm{B}=$ ketebalan film

$\mathrm{C} \quad=$ konsentrasi

(Gowri et al, 2014; Rajini et al, 2013).

\section{Evaluasi Persen Pemanjangan}

Evaluasi persen pemanjangan dilakukan dengan menggunakan instrumen Kinston Universal Testing. Film yang akan diuji akan ditarik dengan menggunakan dua jepitan atau klem dengan kecepatan $100 \mathrm{~mm} / \mathrm{s}$. Kekuatan dan perpanjangan film diukur ssaat film mulai pecah. Rumus persen elongasi dapat ditulis sebagai berikut:

$$
\text { \%pemanjangan }=\frac{\text { penambahan panjang }}{\text { panjang asli }} \times 100
$$

(Rajini et al, 2013)

\section{Evaluasi in vitro (Disintegrasi Film)}

Evaluasi disintegrasi dimaksud untuk menentukan kapan waktu film pecah atau hancur saat kontak langsung dengan air liur. Tes ini dilakukan dengan menempatkan film dalam cairan buffer fosfat. Waktu disintegrasi film yang baik berkisar antara 5-30 detik (Rajini et al, 2013; Archana et al, 2014)

\section{Uji Disolusi}

Uji disolusi dilakukan dengan maksud untuk mengetahui berapa banyaknya zat aktif yang larut didalam medium per waktu pada keadaan standar. Alat yang biasanya digunakan dapat berupa alat disolusi keranjang maupun alat disolusi tipe dayung. Pemilihan media disolusi tergantung kepada kondisi zat aktif. Suhu medium juga harus

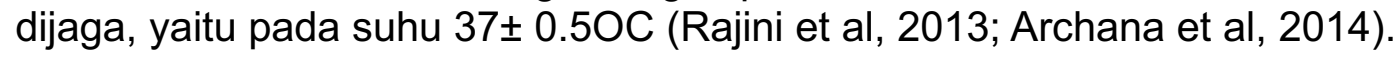




\section{Uji Stabilitas}

Pemeriksaan stabilitas dimaksud untuk mengetahui apakah sediaan stabil pada saat proses penyimpanan atau distribusi. Uji stabilitas juga dilakukan untuk mengetahui apakah pengaruh suhu dan juga kelembaban akan berpengaruh kepada stabilitas sediaan sehingga dengan ini dapat mengetahui kondisi penyimpanan yang tepat untuk sediaan tersebut (Ankita et al, 2013).

\section{Kesimpulan}

Film lapis tipis oral adalah teknologi baru yang memiliki keunggulan dibandingkan dengan sediaan tablet. Film lapis tipis oral memungkinkan pasien anak-anak dan geriatri mudah dalam pemberian dan penerimaan, sehingga meningkatkan kepatuhan pasien serta memaksimalkan penggunaan obat. Akan tetapi tidak semua zat aktif dapat diformulasikan menjadi sediaan film lapis tipis. Zat aktif yang tidak kompatible dengan formulasi tunggal dapat ditambahkan dengan eksipien yang lain sehingga mampu diformulasikan dengan menjadi sediian film lapis tipis oral.

\section{Daftar Pustaka}

Alpesh, R.P., Dharmendra, S., Prajapati, Jignyasha, Raval. 2010. Fast Dissolving films (FDFs) as A Newer Venture in Fast Dissolving Dosage Forms. Int J Drug Dev \& Res. Volume 2.

Ankita, K., Pramod, K.S., Nayyar, P. 2014. Fast Dissolving Oral Film: A Novel And Innovative Drug Delivery System. IJPSR. Volume 5.

Archana, J., Vijaya, V., Uma , M.R. 2014. Formulation and Evaluation of Oral Thin Films Containing Saxagliptin. IJJIPSR. Volume 2.

Arya, A., Chandra, A., Sharma , V., and Pathak K. 2010. Fast Dissolving Oral Films: An Innovative Drug Delivery System and Dosage Form. International Journal of Chem Tech Research. 2 (1).

Apoorva, M., Neha, C., Geeta, A. 2011. Formulation and Characterization of Fast Dissolving Buccal Films: A Review. Der Pharmacia Lettre. Vol. 3.

Avinash, K.G. 2013. Fast Dissolving Dosage Forms. IJPSI. Vol 2.

Bala, R., Pawar, P., Khanna, S and Arora, S. 2013. Orally dissolving strips: A New Approach to Oral Drug Delivery System. International Journal of Pharmaceutical Investigations. Volume 3.

Desai, P. and Basu, B. 2012. Design and Evaluation of Fast Dissolving Films of Domperidone. International research journal of pharmacy. 3 (9). 
Gohel, M.C., Sharma, R., Soniwala, M.M. 2007. Development of Taste Masked Film of Valdecoxib for Oral Use. Ind j Pharm Sci. Vol 69.

Gowri, R., Narayanan, N., Revathy, S., Prabhavathy, P., Preethy, M.G., Rekha, G. 2014. Melt in mouth films-an effective alternative drug delivery system. International Journal of Chem Tech Research 1(2).

Koland, M., Sandeep, V.P., dan Charyulu, N.R. 2010. Fast Dissolving Sublingual Films of Ondansetron Hydrochloride: Effect of Additives on in vitro Drug Release and Mucosal Permeation. J Young Pharm. 2 (3).

Malke, M., Shidhaye, S., and Kadam, V.J. 2007. Formulation and evaluation of Oxacarbazine fast dissolve tablets. Indian J. Pharmaceutical Sci. 69(2).

Mashru, R.C., Sutariya, B.C., and

Parikh, P.P. 2005 Development and Evaluation of Fast Dissolving Films of Salbutamol Sulphate. Drug Dev Ind Pharm. Volume 31.

Mahtre, S., and Khanekar, P. 2012. Rapid dissolving Oral Dosage Form. Journal of global pharma technology. 10(4),

Naziya, K., Raghavendra, N.G., Mahipal, R. 2013. Overview on Fast Dissolving Oral Films. Int J Chem Pharm Sci. Volume 1.

Nehal, S., Garima, G., Pramod, K.S. 2011. A short Review on A Novel Approach in Oral Fast Dissolving Drug Delivery System and Their Patents. Advan Biol Res. Volume 5.

Pandya, K., Patel, K.R., Patel, M.R., Patel, N.M. 2013. Fast Dissolving Films: A Novel Approach To Oral Drug Delivery. Asian Journal of Pharmaceutical Science \& Technology. Volume 3.

Patel, A.R., Prajapati, D.S., and Raval, J.A. 2010. Fast dissolving films (FDFs) As A Newer Venture in Fast Dissolving Dosage Forms. International Journal of Drug. Development and Research. 2 (2).

Priyanka, N., Iti, C., Mohd, Y. 2011. Insights Into Polymers: Film Formers in Mouth Dissolving Films. Drug Invention Today. Volume 3.

Puthil, SP and Dixit, R.P. 2009. Oral strip technology: Overview and Future Potential. Journal of ControlledRelease. 2009. Vol 139.

Rajini, B., Pravin, P., Sushil, K., Sandeep, A. 2013. Orally Dissolving Strips A New Approach To Oral Drug Delivery System. Int J Pharm Investing.Volume 3.

Repka, M.A., Prodduthuri, S., Stodghill, S.P. 2003. Production and Characterization of Hot-melt Extruded Films Containing Clotrimazole. Drug Dev Ind Pharm. Volume 29. 
Sandeep, S., Arun, N., Monika, H.K. 2011. Fast Dissolving Films (FDF): Innovative Drug Delivery System. Pharmacologyonline, Vol. 2.

Shweta, K., Mayank, B. 2012. Recent Trends in The Development Of Oral Dissolving Film. Int J PharmTech Res. Volume 4.

Singh, S., Gangwar, S., Garg, G., Garg V and Sharma, P.K,. 2010. Formulation and Evaluation of Rapidly Disintegrating Film of Levocetrizine Hydrochloride. Scholars Research Library Der Pharmacia Lettre. 2(2).

Sri, R.M., Shaheda, S.K., Mahathi, K., Praveen, P., Prathima, B., Seetha, D.A. 2015. Formulation and Evaluation of Fasdissolving Buccal Film Containing Isradipine Solid Dispersion. Am J PharmTech Res, Vol. 5.

Subash, V.K., Basani, G., Guru, S., Madhusudan, R. 2010. Overview on Fast Dissolving Films. Int J Pharmacy and Pharm Sci. Volume 2.

Swamy, N.G.N., Shiva, K.S. 2014. Formulation and Evaluation of Fast Dissolving Oral Films of Palanosetron Hydrochloride Using HPMC-E5. International journal of pharmaceutical and chemical sciences. Vol. 3. 